\author{
Jurnal Litbang: \\ Media Informasi Penelitian, Pengembangan dan IPTEK \\ http://ejurnal-litbang.patikab.go.id \\ Vol. 16 No. 1 Juni 2020 Hal 1-14
}

\title{
Faktor-Faktor yang Memengaruhi Penolakan Imunisasi Bayi dan Balita pada Masyarakat Sedulur Sikep (Samin)
}

\author{
Factors That Influence Immunization Rejection \\ in The Sedulur Sikep Community (Samin)
}

\author{
Edi Siswanto1)a)*, Ani Margawati2)b), Antono Suryoputro ${ }^{3) c)}$ \\ 1) Mahasiswa Magister Promosi Kesehatan Masyarakat UNDIP Semarang \\ a) JIn Prof. Soedarto SH, Tembalang, Semarang Jawa Tengah \\ 2) Departemen Ilmu Gizi, Fakultas Kedokteran UNDIP Semarang \\ b) Jln Prof. Soedarto SH, Tembalang, Semarang Jawa Tengah \\ 3) Administrasi Kebijakan Kesehatan, Fakultas Kesehatan Masyarakat UNDIP Semarang \\ c) Jln Prof. Soedarto SH, Tembalang, Semarang Jawa Tengah \\ *Email: edisiswantoskm@gmail.com
}

\begin{abstract}
Samin Society is located in the area of Baturejo Village, Sukolilo District, Pati Regency. The initial data of 79 children consist of 2 to 5 years old that have status immunization 1 child completely immunized and 78 children uncompletely immunized. The purpose of this study is to determine the factors that affect the immunization rejection of Samin community in Baturejo Village, Sukolillo District, Pati Regency. This study uses a qualitative approach with a cross sectional observation. Techniques of collecting data included indepth interviews, field-event observation and documentobservation. The technique for determining informants used purposive sampling. The results of this study were: 1) perception that it is not susceptible to the disease due to not immunized, 2) the perception that the disease due to not immunized is not harmful, 3) perception that immunization is no benefit, 4) the perception that the loss or greater obstacles in immunizing their children and 5) cues to act is not conducive to behave immunizing their children.
\end{abstract}

Keywords: samin society, rejection, immunization

\begin{abstract}
ABSTRAK
Masyarakat Samin berada di wilayah Desa Baturejo Kecamatan Sukolilo Kabupaten Pati. Data awal menunjukkan sebanyak 79 anak umur 2 sampai dengan 5 tahun. Satu anak berstatus imunisasi dasar lengkap, sedangkan 78 anak berstatus tidak imunisasi dasar lengkap. Tujuan penelitian ini untuk mengetahui faktor-faktor yang memengaruhi penolakan imunisasi di masyarakat Samin Desa Baturejo Kecamatan Sukolillo Kabupaten Pati. Penelitian ini menggunakan metode kualitatif dengan pendekatan crosssectional dilakukan dengan observasional. Teknik pengumpulan data melalui wawancara mendalam, observasi lapangan, dan observasi dokumen. Teknik penentuan informan dengan teknik purposive sampling. Hasil penelitian ini adalah: 1) persepsi bahwa tidak rentan terhadap penyakit akibat tidak imunisasi, 2) persepsi bahwa penyakit akibat tidak imunisasi tidak membahayakan, 3) persepsi bahwa imunisasi tidak ada manfaatnya, 4) persepsi bahwa kerugian atau hambatan lebih besar dalam mengimunisasi anaknya, dan 5) isyarat untuk bertindak tidak mendukung untuk berperilaku mengimunisasi anaknya.
\end{abstract}

Kata kunci : masyarakat samin, penolakan, imunisasi

\section{PENDAHULUAN}

Masyarakat Sedulur Sikep atau Samin adalah salah satu masyarakat adat yang ada di Indonesia. Keberadaan masyarakat Samin berhubungan erat dengan perlawanan terhadap Kolonial Belanda melalui bentuk perla- wananan tanpa kekerasan serta tidak mau membayar pajak. Era modern ini masyarakat Samin tetap berpegang teguh menjalankan tradisinya dan berinteraksi dengan masyarakat sekitar (Alamsyah, 2015). Masyarakat Samin menganggap pemerintah tidak jujur, maka mereka tidak mau menerima bantuan dari 
pemerintah dan tidak mau mencatatkan perkawinan di catatan sipil (Class, 2014).

Sedulur Sikep memiliki sikap dan perilaku yang lugu bahkan terkesan sangat lugu, berbicara apa adanya, bicara tidak mengenal halus atau kasar karena Sedulur Sikep atau Samin menganggap tindak tanduk lebih penting dari sekedar bahasa yang halus. Sedulur Sikep atau Samin di bagi dua yaitu Jomblo-ito atau Samin Lugu dan Samin Sangkak. Kelompok Samin Sangkak mempunyai sikap pemberani dan melawan hal-hal yang tidak sesuai prinsip keyakinan Sedulur Sikep. Pendatang yang masuk ke komunitas Sedulur Sikep akan dicurigai dan akan dibantah dengan perkataan yang tidak masuk akal (Lestari, 2008; Sa'ida, 2015).

Negara Republik Indonesia dibentuk untuk melindungi segenap bangsa Indonesia. Kesehatan merupakan hak asasi manusia yang dijamin oleh Undang-Undang Dasar Negara Republik Indonesia Tahun 1945 tentang Hak Asasi Manusia Pasal 28 bahwa setiap warga negara berhak hidup di lingkungan yang baik, serta memperoleh pelayanan kesehatan. Pemerintah menyelenggarakan pelayanan di bidang kesehatan untuk meningkatkan kesehatan, pencegahan penyakit, pengobatan, dan pemulihan setelah sakit. Imunisasi untuk bayi dan balita merupakan upaya pemerintah dalam mencegah penyakit yang dapat dicegah dengan imunisasi (Permenkes RI, 2017).

Capaian imunisasi dasar lengkap pada tahun 2017 tingkat nasional sebesar 91,12\%. Capaian ini di bawah target capaian nasional tentang imunisasi dasar lengkap sebesar 92\%. Capaian imunisasi dasar lengkap Jawa Tengah sebesar 98,2\% (Kemenkes RI, 2018). Sementara itu, Kabupaten Pati memperoleh capaian imunisasi dasar lengkap sebesar 103,3\% (DKK Pati, 2017). Capaian imunisasi dasar lengkap pada wilayah Puskesmas Sukolilo 1 sebesar 95,24\% (Puskesmas Sukolilo 1, 2017).

Keberhasilan program imunisasi dapat dilihat dari capaian Universal Child Immuzation (UCI) dengan melihat indikator cakupan imunisasi dasar lengkap yang terdiri dari HBO 1 kali, BCG 1 kali, DPT-HB-Hib 3 kali, Polio 4 kali, campak 1 kali, pada usia 1 tahun dengan cakupan lebih dari atau sama dengan $80 \%$ dari jumlah sasaran bayi di desa. Capaian cakupan desa UCI di Indonesia tahun 2017 sebesar 80,34\%, sedangkan di Jawa Tengah sebesar 99,95\% (Kemenkes RI, 2018). Data dari Dinas Kesehatan Kabupaten Pati menunjukkan bahwa UCI Kabupaten Pati sebesar 100\%. Capaian UCI untuk Puskesmas Sukolilo 1 sebesar 100\%.

Proses penelitian ini dimulai dengan membangun rasa percaya antara peneliti dengan masyarakat Sedulur Sikep (Samin) agar diperoleh data yang akurat. Pertama, peneliti meminta tolong kepada saudara yang memiliki kedekatan dengan tokoh masyarakat Sedulur Sikep (Samin) agar dapat berkomunikasi dan membangun kepercayaan dari tokoh masyarakat Sedulur Sikep (Samin); kedua, dengan mengikuti pendataan Program Indonesia Sehat dengan Pendekatan Keluarga (PIS-PK) di masyarakat Sedulur Sikep (Samin).

Hasil survei awal pada bulan Maret 2019 di lokasi masyarakat Sedulur Sikep (Samin) diperoleh data kelompok anak umur 2 sampai dengan 5 tahun sebanyak 79 anak. Sebanyak 1 orang anak mempunyai status imunisasi dasar lengkap dan 78 orang anak mempunyai status tidak imunisasi dasar lengkap atau tidak imunisasi sama sekali.

Berdasarkan latar belakang tersebut, peneliti bermaksud mengadakan penelitian faktor-faktor yang memengaruhi penolakan imunisasi pada bayi dan balita oleh masyarakat Sedulur Sikep atau Samin di Desa Baturejo Kecamatan Sukolilo Kabupaten Pati. Adapun tujuan penelitian adalah untuk mengetahui faktor-faktor penolakan imunisasi pada masyarakat Samin Desa Baturejo dengan melihat persepsi kerentanan yang dirasakan (perceived susceptibility), persepsi keseriusan penyakit (perceived severity), persepsi manfaat yang dirasakan (perceived benefit), persepsi hambatan yang dirasakan (perceived barrier), dan isyarat berkehendak (cues toaction) dalam imunisasi. 


\section{TINJAUAN PUSTAKA}

\section{Imunisasi}

Setiap bayi dan anak berhak mendapatkan imunisasi lengkap. Hal ini merupakan tanggung jawab dan kewajiban pemerintah (UU RI, 2009). Imunisasi adalah proses menumbuhkan kekebalan atau menambah kekebalan ke dalam tubuh sehingga apabila terkena suatu penyakit menjadi tidak sakit atau sakit ringan. Imunisasi dasar adalah bagian dari imunisasi rutin, dimana imunisasi dasar di berikan pada anak usia di bawah 1 tahun. Jadwal pemberian imunisasi dasar adalah: HBO pada umur waktu dilahirkan sampai 24 jam, Imunisasi BCG dan Polio 1 pada umur 1 bulan, Imunisasi DPT-HBHib 1 dan polio 2 pada bayi umur 2 bulan, Imunisasi DPT-HB-Hib 2 dan Polio 2 di berikan bayi umur 3 bulan, Imunisasi DPT-HB-Hib 3 Polio 4 di berikan pada bayi umur 4 bulan dan imunisasi campak di berikan pada bayi umur 9 bulan (Kemenkes RI, 2017). Seiring dengan keberhasilan program imunisasi, terdapat kejadian paska imunisasi (KIPI). Menurut komite nasional pengkajian dan penanggulangan KIPI, kejadian ikutan paska imunisasi adalah kejadian sakit atau meninggal pada anak setelah imunisasi sampai 1 bulan (Widyastuti, 2017).

\section{Samin}

Saminisme adalah ajaran yang mengikuti pendirinya, yaitu Samin Surosentiko. Konsep ajarannya adalah melawan penjajah Kolonialis Belanda dengan pembangkangan untuk tidak tunduk dengan Pemerintah Belanda (Mardikantoro, 2017). Samin berasal dari kata "sami-sami" yang mempunyai arti semua manusia sama, yang membedakan adalah keinginannya. Ajaran samin berkembang dari Ploso Kadiren, kemudian berkembang ke daerah sekitarnya, dan berkembang ke Kabupaten Bojonegoro, Tuban, Pati, dan Kudus. Tokoh Samin menyebarkan ajaran Samin dengan cara mendatangi saudara-saudaranya (Alamsyah,
2015). Masyarakat Samin dalam berkomunikasi dibagi menjadi 4 yaitu: pertama, Samin Sangkak yaitu menjawab pertanyaan sesuai apa yang dilakukan, misalnya ditanya dari mana maka dijawab dari belakang; kedua, Samin Samiroto, yaitu Samin yang sudah menerima budaya luar; ketiga, Samin Amping-amping Grogol atau nyamin, dimana mengaku Samin tetapi tingkah lakunya tidak mencerminkan orang Samin; keempat, Samin dlejet atau ndledek, dimana seorang Samin yang masih berpegang teguh pada budaya. Ajaran Samin diantaranya mengajarkan agar pengikut Samin tidak boleh mengumbar hawa nafsu, memfitnah orang lain (drengki), menguasai milik orang lain yang bukan haknya (srei), mudah tersinggung dan bermusuhan dengan orang lain (panasten), menuduh orang lain dengan membabi buta (dahwen), ingin memiliki milik orang lain (kemeren), tidak boleh mengambil barang orang lain. Orang Samin menganggap agama adalah pandangan hidup yang harus diikuti oleh orang Samin. Agama orang Samin adalah Agama Adam yang mempunyai arti: pertama, agama adalah "gaman", Adam adalah pangucape, "man gaman lanang". Agama adalah suatu pusaka yang menjadi pegangan hidup dimana berisi hal-hal tentang apa yang boleh dilakukan dan tidak boleh dilakukan dalam hubungan dengan sesama manusia; kedua "ing sakjroning agama ana roso, roso sejatine roso, roso sejatine wujud banyu" (di dalam agama ada rasa di dalam rasa ada rasa, dan dalam rasa berbentuk air), artinya bahwa agama seperti air yang suci, semua manusia membutuhkan agama seperti membutuhkan air sebagai unsur kehidupan; ketiga "Sukmo ngawulo rogo, rogo ngawulo sworo" (Sukma tercermin dari raga, raga tercermin dari suara), artinya bahwa jiwa yang baik dilandasi agama dan akan terlihat dari perilaku yang baik, antara perilaku dan perkataan yang seimbang mengatakan yang sesungguhnya yang merupakan kebenaran jiwa dan raga (Mardikantoro, 2017). Sedulur 
Sikep (Samin) mempunyai prinsip dalam hidup yaitu berperilaku yang baik. Perilaku yang baik dapat dilihat dari tiga hal yaitu: (1) tidak berbohong pada diri sendiri maupun orang lain, (2) menjaga lisan artinya orang dapat dipercaya karena ucapannya, (3) yang dibutuhkan isinya bukan luarnya, artinya orang hidup harus lahir batin bukan lahirnya baik tapi batinnya jelek (Sri \& Lestari, 2017). Sebagian masyarakat saat ini memandang Sedulur Sikep (Samin) sebagai komunitas aneh atau kelompok nyeleneh. Cara pandang tersebut kemungkinan disebabkan masih terbatasnya pengetahuan dan pemahaman tentang masyarakat Sedulur Sikep (Trianingsih dkk., 2017).

\section{Health Belief Model (HBM)}

Health Belief Model atau HBM adalah teori perubahan perilaku yang digunakan untuk memprediksi perilaku tentang kesehatan dengan mendasarkan kepada kepercayaan dan persepsi seseorang terhadap penyakit. Persepsi kepercayaan individu terhadap penyakit adalah persepsi subjektif. Ada beberapa persepsi atau kepercayaan individu yang memengaruhi pengambilan keputusan dalam menentukan apa yang terbaik bagi dirinya yaitu: pertama adalah kerentanan yang dirasakan (perceived susceptibily), dimana apabila individu merasa rentan terhadap penyakit yang ditimbulkan akibat tidak diimunisasi, maka individu tersebut akan berusaha mencegah dengan imunisasi; kedua adalah keseriusan penyakit yang dirasakan (perceived severity), artinya bila individu mempunyai persepsi serius terhadap penyakit akibat tidak diimunisasi, maka individu tersebut akan berusaha untuk mencegah penyakit dengan imunisasi. Keseriusan penyakit ini bisa di perolah dari informasi kesehatan atau pengetahuan tentang imunisasi; ketiga adalah persepsi manfaat (perceived benefit) yang dirasakan, dimana persepsi individu tentang manfaat yang akan diperoleh setelah imunisasi; keempat adalah persepsi hambatan (perceived barrier), yaitu persepsi hambatan yang akan diperoleh apabila mengimunisasi anak. Apabila persepsi terhadap manfaat yang dirasakan lebih besar daripada persepsi hambatan, kemungkinan individu tersebut akan mengimunisasi anak; keempat adalah persepsi tersebut dipengaruhi oleh dua komponen yaitu variabel modifikasi yang terdiri dari faktor demografi dan sosiopsikologi; dan isyarat untuk bertindak (cues toaction) yang terdiri dari kontak petugas, akses informasi dan pengalamanpengalaman pribadi atau dari masyarakat tentang efek samping setelah pemberian imununisasi (Priyoto, 2018).

\section{METODE PENELITIAN}

Penelitian menggunakan metode kualitatif dengan pendekatan crosssectional dan dilakukan dengan observasional. Penelitian ini dilakukan pada masyarakat Sedulur Sikep (Samin) di Desa Baturejo Kecamatan Sukolilo Kabupaten Pati pada bulan Agustus 2019 sampai dengan Oktober 2019. Informan utama dalam penelitian adalah ibu yang mempunyai anak umur 2 sampai 5 tahun, terdiri dari 1 orang ibu yang mengimunisasi dasar lengkap anaknya (IU1) dan 5 orang ibu yang tidak mengimunisasi dasar lengkap anaknya (IU2 sampai IU6). Informan triangulasi terdiri dari 1 orang bidan desa (IT1), 1 orang kader posyandu (IT2), 1 orang tokoh Samin (IT3).

Teknik pengambilan sampel dalam penelitian ini dengan purposive sampling yaitu pengambilan sampel melalui pertimbangan peneliti itu sendiri dan dengan tujuan tertentu (Sugiyono, 2016). Pemilihan informan utama dianggap yang paling mengetahui tentang sebab anaknya diimunisasi atau tidak diimunisasi pada masyarakat Sedulur Sikep (Samin) Desa Baturejo Kecamatan Sukolilo Kabupaten Pati. 
Instrumen dalam penelitian ini adalah peneliti sendiri sebagai instrumen utama dalam pengumpulan data dan pedoman wawancara mendalam semiterstruktur tentang gambaran pemberian imunisasi dasar lengkap. Data yang digunakan adalah data primer dan data sekunder. Teknik pengumpulan data dengan wawancara mendalam pada informan utama dan triangulasi, observasi kegiatan posyandu melati 4, dan dokumentasi. Teknik pengabsahan data dengan teknik triangulasi. Teknik analisis data sesuai yang disampaikan oleh Miles dan Huberman dengan cara interaktif secara terus menerus sehingga data jenuh. Langkahlangkah penelitian yaitu pengumpulan data, reduksi data, display data, kesimpulan atau verifikasi data (Sugiyono, 2018).

\section{HASIL DAN PEMBAHASAN}

\section{Gambaran Karakteristik Informan}

Gambaran karakteristik informan dilihat dari usia (KTP) antara 30 sampai 40 tahun. Hasil wawancara mendalam terhadap 4 orang informan utama yang mempunyai suami orang dari dalam masyarakat Samin dan 1 orang informan triangulasi tokoh masyarakat Samin mengatakan bahwa umur bukan hal yang penting dan tidak dicatat, maka dalam wawancara mendalam ketika ditanya tentang umur menjawab:

"sepisan kanggo sak lawase."

Artinya umur itu langgeng adanya. Dua orang informan utama yang mempunyai suami orang di luar masyarakat Samin saat ditanya tentang umur, mengatakan umurnya, menjawab:

"kira..."

Masyarakat Sedulur Sikep (Samin) juga tidak tahu umur anak. Mereka tidak mencatat tanggal, bulan, dan tahun kelahiran anak. Hal tersebut juga disampaikan informan triangulasi bahwa tidak datang ke posyandu karena takut jika ditanya tentang umur anak, karena umur tidak dicatat. “...ditakoni umure pirang tahun, niki di imunisasekke ping pinten, padahal anak turun teng mriki lahire dino nopo sasi nopo wulan nopo niku jarang diteliti, pramilo dari pada engko ditakoni jawabane ora pas alah ora penak mending ora usah imunisasi." (IT3)

Artinya: "di tanya umurnya berapa tahun, ini diimunisasi berapa kali, padahal masyarakat di sini lahir hari, bulan apa tidak dicatat, oleh sebab itu daripada ditanya jawabanya tidak sesuai lebih baik tidak diimunisasi."

Tanggal lahir anak tidak dicatat oleh orang tua, menyebabkan orang tua tidak tahu kapan jadwal imunisasi anaknya. Kegiatan pencatatan tanggal kelahiran dilakukan oleh bidan desa sewaktu kunjungan rumah setelah ibu melahirkan. Hasil penelitian ini sejalan dengan penelitian di Warao Ameredian Venezuela, dimana orang tua tidak mengetahui umur anaknya menyebabkan kesulitan orang tua mengetahui jadwal anaknya untuk imunisasi. Petugas kesehatan, kader, dan perangkat desa semakin berat tugasnya untuk mendatangi sasaran apabila kegiatan posyandu akan dilakukan (Burghouts et al., 2017).

Orang Samin tidak belajar di sekolah formal. Keenam informan utama tidak mengikuti sekolah formal. Ketika mereka ditanya tentang sekolah atau pendidikan, menjawab:

"sekolah macul, sekolah masak."

Empat informan utama yang mempunyai suami orang masyarakat Sedulur Sikep (Samin) tidak menyekolahkan anaknya di sekolah formal, tetapi "sinau moco nulis" di rumah kang Gunritno, seorang tokoh muda Samin dengan tujuan sekedar bisa membaca dan menulis. Dua informan utama yang mempunyai suami dari luar Samin menyekolahkan anaknya di sekolah formal.

Hal tersebut sejalan dengan penelitian sebuah model pembelajaran dalam komunitas Samin di Sukolilo Pati bahwa sekolah formal dipahami sebagai tempat mencari kepandaian yang selanjutnya akan digunakan membodohi 
atau menipu orang lain. Pemahaman itu didasari dari pengalaman pada waktu penjajah membodohi masyarakat Indonesia. Masyarakat Samin mempunyai konsep pembelajaran sekolah biasa yang dilakukan di rumah yang diajarkan orang tua adalah sinau nulis, sinau kehidupan (Darmastuti \& Prasela, 2010).

Upaya Kesehatan Berbasis Masyarakat (UKBM) posyandu Melati empat adalah satusatunya pelayanan posyandu pada masyarakat Sedulur Sikep. Kegiatan tersebut dilaksanakan setiap bulan tanggal 10 di rumah kader posyandu. Kader posyandu Melati 4 berjumlah 2 orang, dengan 1 orang kader sedang hamil besar. Mereka mempunyai pemahaman bahwa posyandu adalah milik puskesmas. Kegiatan posyandu hanya terdapat satu meja untuk pelayanan kegiatan tersebut. Peran serta masyarakat dalam kegiatan posyandu sangat kurang. Hasil observasi menunjukkan bahwa posyandu tersebut tidak sejalan dengan teori tentang posyandu, yakni posyandu adalah milik desa, jumlah kader posyandu minimal 5 orang, dan sistem 5 langkah dalam kegiatan posyandu, yaitu: pendaftaran, penimbangan, pengisian KMS, penyuluhan, dan pelayanan kesehatan. (Kemenkes RI, 2011).

Hasil dalam penelitian ini menunjukkan bahwa masyarakat Samin telah mengadopsi perilaku kesehatan dengan melakukan suntik KB dengan tujuan agar jumlah anaknya tidak banyak. Perubahan perilaku tersebut karena masyarakat Samin telah mengetahui manfaat ber-KB. Perilaku kesehatan lain masyarakat Samin adalah melahirkan di fasilitas kesehatan/ puskesmas. Perubahan tersebut karena kesepakatan bersama antara dukun beranak, muspika, dan puskesmas tentang aturan yang menjelaskan bahwa semua persalinan harus di fasilitas kesehatan/puskesmas. Aturan tersebut bertujuan untuk menurunkan angka kesakitan dan kematian ibu dan bayi. Hal tersebut sejalan dengan penelitian yang dilakukan di Puskesmas Kabupaten Pati yang menyatakan bahwa untuk menurunkan angka kematian ibu, dilakukan dengan cara semua persalinan berada di fasilitas kesehatan/puskesmas (Nafiah \& Setiawati, 2019).

\section{Persepsi Kerentanan yang Dirasakan (Perceived Susceptibility)}

Pemberian imunisasi mempunyai tujuan untuk mecegah penyakit yang dapat dicegah dengan imunisasi (Kemenkes RI, 2017). Hasil penelitian pada informan utama yang anaknya diimunisasi dasar lengkap, mempercayai bahwa imunisasi dapat mencegah penyakit. Jika anaknya tidak diimunisasi, maka akan rentan terhadap penyakit.

“... sanjange saget mencegah penyakit nopo, menurut kulo katah manfaate menurut dokter saget mencegah penyakit..." (IU1)

Artinya: "...bisa untuk mencegah penyakit apa menurut dokter dapat mencegah penyakit..."

Informan utama yang tidak mengimunisasikan anaknya mempunyai persepsi bahwa pencegahan penyakit dilakukan dengan berdoa agar tidak sakit dan juga memiliki persepsi bahwa penyakit tidak dapat dicegah karena pemberian Tuhan yang tidak dapat dihindari.

"Mugo-mugo ora ketisen (dongo) mboten gadah kepercayaan angger awake dewe." (IU2)

Artinya: "semoga tidak sakit (doa) tidak punya kepercayaan, yang penting badannya sendiri."

"Mugo-mugo awak waras terus (doa)." (IU3)

Artinya: "Semoga badannya sehat terus."

"...mboten saget sebeb niku mboten saget diemohi mboten saget di suwun." (IU4)

Artinya: "...tidak bisa sebab penyakit tidak dapat di minta dan tidak bisa di tolak."

Hal ini sejalan penelitian di Sleman tentang penyakit campak bahwa penyakit tidak dapat dicegah karena pemberian Tuhan (Wahyunarni, Ahmad, \& Ratnawati, 2018). Tahun 2005 di wilayah Sedulur Sikep (Samin) terdapat seorang anak yang terkena penyakit Polio (Puskesmas Sukolilo I, 2017). Penyakitpenyakit yang dapat dicegah dengan imunisasi 
dapat timbul kembali karena sebagian besar anak bayi dan balita tidak terlindungi dengan imunisasi. Hal tersebut sejalan dengan artikel new detik health yaitu satu dua anak di wilayah tertentu tidak mendapat imunisasi, memicu timbulnya penyakit menular yang pernah ada di masyarakat tersebut (detik health, 2015).

Masyarakat Samin yang tidak mengimunisasi dasar lengkap anaknya mempunyai persepsi bahwa tidak imunisasi tidak apa-apa, tidak imunisasi tetap sehat sampai tua. Hal ini disampaikan oleh informan utama:

"Kepercayaane ora diimunisasi yo seger waras, ora dimunisasi yo tuk tuwek." (IU2)

Artinya: "Kepercayaan diri sendiri bahwa tidak diberi imunisasi tetap sehat, tidak diimunisasi tetap hidup sampai tua."

Hasil penelitian ini menunjukan bahwa informan yang tidak mengimunisasi dasar lengkap anaknya merasa bahwa anaknya tidak rentan terhadap penyakit apabila anak tidak diimunisasi. Semakin merasa tidak rentan terhadap penyakit akibat tidak diimunisasi, maka individu tersebut tidak mengimunisasikan anak (Priyoto, 2018). Hal ini menguatkan hasil penelitian ini bahwa masyarakat Sedulur Sikep (Samin) mempunyai persepsi tidak rentan terhadap penyakit akibat tidak imunisasi. Penelitian ini sejalan dengan penelitian yang dilakukan di Puskesmas Panumping dan Puskesmas Bayuanyar bahwa ibu yang mempunyai persepsi anak lebih rentan terhadap penyakit apabila tidak diimunisasi, maka akan mengimunisasikan anaknya dibandingkan dengan ibu yang tidak mempunyai persepsi kerentanan pada anak akibat tidak diimunisasi (Puri, 2016). Hasil penelitian tersebut juga sejalan dengan penelitian di Kelurahan Pampang Makasar bahwa orang tua mengimunisasikan anaknya karena mempunyai persepsi kerentanan yang dirasakan apabila anaknya tidak diimunisasi (Ary, 2014).

\section{Persepsi Keseriusan Bahaya yang Dirasakan (Perceived Severity)}

Individu yang memiliki persepsi terhadap bahaya yang dirasakan apabila anak tidak diimunisasi, maka mempunyai peluang lebih besar untuk mengimunisasi anaknya. Persepsi keseriusan bahaya yang dirasakan diperoleh dari informasi kesehatan dan pengetahuan tentang imunisasi (Priyoto, 2018). Hasil penelitian menunjukkan bahwa informan utama, ibu yang mengimunisasi dasar lengkap mempunyai persepsi bahwa apabila anak tidak diimunisasi, maka akan sering sakit panas.

"Seng riyen anake kulo rak panas terus, Iha sanjange dokter pas kulo beto teng rumah sakit kulo ditangleti anake njenengan mboten diimunisasi? Kulo jawab enggeh opo nyatane, terus kula angen-angen menawi kulo gadah anak kulo imunisasi." (IU1)

Artinya: "Yang dulu, anak saya panas terus. Saya bawa ke rumah sakit, kemudian dokter tanya apakah anak saya tidak diimunisasi? saya jawab jujur ya, setelah itu saya mempunyai angan-angan kalau punya anak lagi saya imunisasi."

Informan yang tidak mengimunisasi dasar lengkap anaknya mempunyai persepsi bahwa imunisasi hanya untuk anak yang sakit. Persepsi tersebut disebabkan karena pengalaman anak yang pertama lahir dengan berat badan 200 gr, kemudian berat badannya meningkat setelah diimunisasi. Anak yang sehat tidak perlu imunisasi. Hal tersebut di sampaikan oleh informan utama sebagai berikut:

"Riyen peh lahir alit, dereng wonten kalih kilo.. iki durung rong tahun tak imunisasi mbak. terus lemu kok." (IU3)

Artinya: "Dulu di rumah sakit di imunisasi, dulu karena berat badannya kurang dari dua kilo, petugasnya bilang ini belum ada dua tahun saya imunisasi, setelah diimunisasi berat badanya bertambah."

Penelitian ini tidak sejalan dengan informasi kesehatan bahwa imunisasi tidak boleh diberikan kepada anak yang sakit batuk pilek, diare, minum antibiotik, epilepsi, panas tinggi, dan alergi (Noya, 2018).

Hasil penelitian ini menunjukkan bahwa semua informan utama tidak bisa menjawab definisi imunisasi, manfaat imunisasi, jenis 
imunisasi, dan jadwal tiap jenis imunisasi. Hal ini dapat diartikan bahwa pengetahuan masyarakat Sedulur Sikep (Samin) tentang imunisasi sangat kurang. Ada fenomena yang menarik pada informan utama yang mengimunisasi anak dasar lengkap pada anaknya, yaitu meskipun mempunyai pengetahuan yang kurang tetapi tetap mengimunisi anaknya.

"Kulo mboten retos butohe anake kulo imunisasi teng puskesmas ben sehat ngoten mawon." (IU1)

Artinya: "Saya tidak tahu, yang penting anak saya imunisasikan di puskesmas biar sehat."

Terdapat hubungan antara pengetahuan dengan penerimaan imunisasi. Ibu yang mempunyai pengetahuan tentang imunisasi yang baik memiliki kelengkapan status imunisasi yang baik pula (Prabandari dkk., 2018). Hasil penelitian ini menunjukkan adanya persepsi bahwa imunisasi hanya untuk orang sakit, maka anak sehat tidak perlu imunisasi. Pengetahuan yang kurang tentang imunisasi mengindikasikan bahwa masyarakat Sedulur Sikep (Samin) mempunyai persepsi tidak serius atau tidak bahaya apabila terkena penyakit akibat tidak diimunisasi. Hasil tersebut sejalan dengan penelitian di Puskesmas Banyuanyar dan Puskesmas Panumping menjelaskan bahwa terdapat hubungan positif antara persepsi keseriusan dan kelengkapan status imunisasi (Puri, 2016).

Keseriusan yang dirasakan terhadap penyakit dapat dilihat dari konsep sehat dan sakit serta bagaimana mencari pertolongan apabila anak sakit. Hasil penelitian ini menunjukkan bahwa anak sakit diberi "bobok" (dari daundaunan) dan dibawa ke dukun pijat. Apabila tidak sembuh, maka anak dibawa ke petugas kesehatan atau sebaliknya. Penelitian ini sejalan dengan penelitian di Sleman bahwa masyarakat melakukan pengobatan secara tradisional dan apabila tidak sembuh, maka akan dibawa ke pengobatan modern (Wahyunarni dkk., 2018).

\section{Persepsi Manfaat yang Dirasakan (Perceived Benefit)}

Seseorang akan mengimunisasikan anaknya apabila mempunyai persepsi bahwa imunisasi mempunyai banyak manfaat untuk anaknya, mencegah penyakit akibat tidak di imunisasi (Priyoto, 2018). Hasil penelitian ini menunjukkan bahwa informan yang mengimunisasi dasar lengkap pada anaknya mempunyai persepsi bahwa imunisasi dapat mencegah penyakit dan supaya tidak sering sakit panas. Informan yang tidak mengimunisasi anaknya mempunyai persepsi bahwa imunisasi tidak ada manfaatnya, apabila tidak diimunisasi tetap sehat dan bugar. Hal ini di sampaikan informasi utama sebagai berikut:

"Kepercayaane ora di imunisasi yo seger waras, ora diimunisasi yo tuk tuwek." (IU2)

Artinya: "kepercayaan diri sendiri bahwa tidak diberi imunisasi tetap sehat, tidak diimunisasi tetap hidup sampai tua."

Kepercayaan tersebut diperkuat dengan persepsi informan triangulasi tokoh Samin sebagai berikut:

"Nggeh kulo matur opo entene, nek menurut pemahamane kulo wong loro siji diimunisasi siji ora ... kesehatane podo,..." (IT3)

Artinya: "Saya mau bicara apa adanya, kalau menurut saya ada orang satu diimuniisasi dan yang satu tidak diimunisasi, sama-sama sehat."

Masyarakat Sedulur Sikep mempunyai persepsi bahwa imunisasi tidak ada manfaatnya. Persepsi tersebut merupakan salah satu faktor untuk menolak mengimunisasi anaknya ke posyandu. Penelitian ini tidak sejalan dengan penelitian di Kelurahan Pampam bahwa ibu-ibu mempunyai persepsi bahwa imunisasi mempunyai manfaat yang sangat besar pada anaknya. Persepsi ini memengaruhi kelengkapan imunisasi pada anaknya (Ary, 2014).

Hal tersebut sesuai dengan penelitian Yulia dalam Wahyunarni dkk. (2015) bahwa masyarakat tidak mengetahui manfaat imunisasi, serta membandingkan anak yang 
diimunisasi dengan yang tidak diimunisasi tetap sakit, menjadi penyebab ibu tidak mengimunisasi anaknya. Selain itu, persepsi bahwa setelah diimunisasi masih bisa terkena penyakit menimbulkan keraguan untuk mengimunisasikan anaknya (Sulistiyani, 2017).

\section{Kerugian atau Hambatan yang Dirasakan (Perceived Barrier)}

Hasil penelitian menunjukkan bahwa hambatan yang dirasakan jika mengimunisasikan anaknya sangat besar. Hal tersebut tertuang dalam hasil wawancara sebagai berikut:

"nggeh bar imunisasi engko nek panas." (IU3, IU6)

Artinya: "ya setelah imunisasi panas."

"nek diimunisasi kados bintol dados wedi, nate diparingi tetes, wedi suntik, nggeh wedi seng ngoteniku .. sakit panas." (IU4)

Artinya: "kalau di imunisasi seperti bengkak jadi takut, dulu pernah diberi tetes tapi kalau suntik takut, takut sakit panas."

Persepsi ini diperkuat oleh informan triangulasi kader kesehatan sebagai berikut:

"Pengalaman efek samping di masyarakat adalah panas, rewel, kemudian orang tua tidak bisa bekerja karena anaknya sakit." (IT1)

Individu dengan persepsi bahwa semakin banyak hambatan atau kerugian dibandingkan manfaat setelah imunisasi, maka orang tersebut tidak akan mengimunisasikan anaknya atau sebaliknya (Priyoto, 2018). Hal tersebut selaras dengan penelitian dengan lokasi Kelurahan Pampam, Puskesmas Banyuanyar, dan Puskesmas Panumping bahwa ibu dengan persepsi hambatan lebih besar daripada manfaat imunisasi, maka akan berpeluang kemungkinan tidak mengimunisasi anaknya (Ary, 2014; Puri, 2016).

\section{Isyarat untuk bertindak (Cues to Action)}

Isyarat untuk bertindak adalah faktor eksternal yang memengaruhi perilaku untuk mengimunisasi anak. Isyarat bertindak dapat berasal dari informasi tentang imunisasi, akses informasi, kontak petugas, dan pengalaman- pengalaman tentang kejadian paska imunisasi atau efek samping imunisasi (Priyoto, 2018).

Hasil penelitian ini menunjukkan bahwa masyarakat sedulur Sikep (Samin) memperoleh akses informasi dari TV, radio, informasi dari kader posyandu, perangkat desa, dan petugas kesehatan. Sebelum kegiatan posyandu dilakukan, kader dan perangkat desa memberi informasi kepada masyarakat Samin tentang adanya kegiatan posyandu. Hal ini karena masyarakat Samin tidak tahu tanggal dan bulan Nasional, seperti yang di sampaikan informan triangulasi kader posyandu sebagai berikut:

"Kalau di sini dioyaki biasane ya pada datang menimbangkan, tapi tidak mau diimunisasi karena tidak sekolah tidak tahu tanggalan, tapi kalau ngoyaki terus ya bagaimana ya pak." (IT2)

Kegiatan memberi tahu warga setiap kali kegiatan posyandu akan dilaksanakan menimbulkan rasa jenuh pada kader dan perangkat desa. Hal tersebut di sampaikan oleh informan triangulasi sebagai berikut:

“di sini saja pak RT 1 RW 2, kadang sampai timur tepi jalan tapi kalau orangnya malas aku juga malas pak. Kemarin minta bantuan sama perangkat...perangkatnya bilang tanggal 10 ada posyandu di rumah mbak Yesi, tapi juga tidak datang. Perangkat itu cara memberi tahu keliling secara sekilas tidak yang sasaran saja." (IT2)

Informasi kesehatan memang sudah masuk melalui media yang ada, tetapi hal tersebut tidak menjamin informasi itu sampai dengan baik. Hal tersebut tergantung dari individunya, apakah mau menerima atau tidak. Seperti yang disampaikan oleh informan triangulasi tokoh masyarakat sebagai berikut:

"Nek masalah sworo sampun tepuk, enggeh saking bu bidan, pak mantri, saking TV saking pak dokter nek mirenge nggeh tetep mireng." (IT3)

Artinya: "Kalau tentang informasi sudah menyeluruh, dari bu bidan, perawat, TV, dokter kalau didengarkan pasti mendengar."

Penelitian ini sejalan dengan penelitian di Klopoduwur Blora bahwa budaya populer telah mempengaruhi masyarakat Samin dengan 
ditandai penggunaan radio, $\mathrm{TV}, \mathrm{Hp}$, dan peralatan modern lainnya oleh masyarakat tersebut(Ken, 2017).

Kegiatan posyandu dilakukan setiap bulan tanggal 10. Hasil observasi kader posyandu hanya 2 orang dan tempat posyandu hanya 1 meja. Tidak ada layanan imunisasi karena tidak ada sasaran yang datang imunisasi. Pelayanan posyandu hanya penimbangan bayi dan balita. Kegiatan imunisasi bertepatan waktu untuk ke sawah, tidak ada layanan sistem lima meja, dan penyuluhan kesehatan pada meja keempat tidak ada. Seperti yang disampaikan informan yang mengimunisasikan anaknya sebagai berikut:

"Posyandu teng mbak Yesi, neng anakke kulo kulo imunisasi wonten Puskesmas, la sanjange imunisasi teng pundi kulo, teng balai desa, terose bu bidan nek teng balai desa obate emaneman sebab seng imunisasi sekedik, saene teng puskesmas mawon." (IU1)

Artinya: "Posyandu di rumah mbak Yesi (posyandu Melati 4), tapi anak saya imunisasikan di puskesmas, katanya di balai desa, kalau yang imunisasi sedikit obatnya sudah tidak bisa dipakai lagi, maka di suruh ke puskesmas saja."

Hal ini diperkuat oleh informan triangulasi bidan desa sebagai berikut:

" tidak ada...pernah ada satu maka tidak saya imunisasi dan saya suruh ke puskesmas karena kalau satu orang maka sisa obat tidak dapat digunakan lagi,...” (IT1)

Hasil penelitian ini menunjukkan bahwa informan utama yang mengimunisasi dasar anaknya mempunyai pengalaman efek samping setelah imunisasi, yakni anaknya panas. Meskipun demikian, informan mempunyai persepsi bahwa manfaat imunisasi lebih besar dari efek samping yang ditimbulkan. Selain itu, juga melihat saudara yang terkena penyakit Polio akibat tidak diimunisasi, sehingga termotivasi untuk mengimunisasi anaknya.

“...neng sederek kulo (H) mboten diimunisasi panas malah dugi sak niki mboten saget mlaku (haryanto positif polio pada tahun 2005)." (IUI)
Artinya: “...saudara saya (H) tidak diimunisasi panas kemudian sampai sekarang tidak bisa jalan (H positif Polio tahun 2005).

Sementara itu, informan utama yang tidak mengimunisasi dasar anaknya memiliki pengalaman efek samping imunisasi yang didengar dari masyarakat bahwa imunisasi memiliki efek samping anak menjadi panas sehingga orang tua tidak bisa bekerja.

"Nggeh bar imunisasi engko nek panas." (IU3, IU4, IU6)

Artinya: "Ya setelah imunisasi panas."

"Riyen wonten jare bar diimunisasi tangane aboh, dados wong Sikep rak wedi." (IU2)

Artinya: "Dulu katanya setelah diimunisai tangannya bengkak, jadi orang Sikep takut."

Seorang informan utama mendengar dari masyarakat dan melihat dari media televisi bahwa ada peristiwa seorang anak yang meninggal dunia setelah diimunisasi.

"Nggeh panas...teng TV kadang bar imunisasi meninggal inggeh wonten." (IU4)

Artinya: "Ya menyebabkan panas...di TV kadang setelah imunisasi ada yang meninggal."

Hasil wawancara tersebut didukung oleh informan triangulasi bidan desa sebagai berikut:

"Pengalaman efek samping di masyarakat adalah panas, rewel, kemudian orang tua tidak bisa bekerja karena anaknya sakit." (IT1)

Penelitian ini sejalan dengan penelitian Rahmawati \& Wahyuni (2014) bahwa persepsi imunisasi membawa dampak buruk terjadi pada para ibu yang memiliki anak dengan status imunisasinya tidak lengkap, sedangkan persepsi imunisasi tidak mempunyai dampak buruk terjadi pada ibu-ibu yang mempunyai anak dengan status imunisasinya lengkap.

Isyarat untuk bertindak adalah faktor ekternal yang memengaruhi perilaku mengimunisasi anak. Hasil penelitian menunjukkan bahwa akses terhadap informasi budaya populer (televisi, radio, dan HP) cukup baik, namun tidak berpengaruh terhadap peningkatan pengetahuan tentang imunisasi. Kontak 
dengan petugas untuk mendapatkan informasi tentang imunisasi kurang, sarana prasarana, serta kompetensi kader kesehatan tidak sesuai dengan standar pelayanan posyandu. Pengalaman efek samping imunisasi, baik pada dirinya maupun yang bersumber dari masyarakat, menghambat isyarat untuk bertindak dan mendorong untuk tidak mengimunisasi anaknya.

Penelitian ini bertentangan dengan penelitian di Puskesmas Kenjeran Surabaya bahwa petunjuk untuk bertindak adalah faktor eksternal yang mendorong perilaku untuk mengimunisasikan anak. Peran yang sangat penting dari petugas kesehatan, kader dalam menginformasikan kesehatan, dan peran media yang memengaruhi isyarat untuk bertindak (Utviaputri, 2018).

\section{KESIMPULAN DAN SARAN}

\section{Kesimpulan}

Faktor-faktor yang memengaruhi penolakan imunisasi di masyarakat Sedulur Sikep (Samin) diantaranya: (1) persepsi tidak rentan terhadap penyakit akibat tidak imunisasi; (2) persepsi bahwa penyakit akibat tidak imunisasi tidak membahayakan yang didukung oleh pengetahuan masyarakat Samin tentang imunisasi yang kurang; (3) persepsi imunisasi tidak ada manfaatnya; (4) Persepsi bahwa kerugian atau hambatan lebih besar dalam mengimunisasi anak; dan (5) isyarat untuk bertindak tidak mendukung untuk berperilaku mengimunisasi anak.

\section{Saran}

Puskesmas Sukolilo 1 perlu mengadakan pendekatan ke masyarakat serta tokoh Samin dalam upaya peningkatan pengetahuan tentang imunisasi, refresing kader posyandu tentang imunisasi, dan pengkajian ulang jam posyandu. Pemerintah Desa Baturejo menambah sarana prasarana posyandu dan menambah jumlah kader posyandu Melati 4, pemberian reward untuk kader posyandu, meningkatan peran serta masyarakat dalam kegiatan posyandu di daerah masyarakat Sedulur Sikep (Samin).

\section{DAFTAR PUSTAKA}

Alamsyah. (2015). Eksistensi dan Nilai-Nilai Kearifan Komunitas Samin di Kudus dan Pati. Humanika, 21(1), 63-74.

Ary, D. (2014). Pemanfaatan Imunisasi di Kelurahan Pampang Kecamatan Panakkukang Kota Makassar (Pendekatan Health Belief Model) (Skripsi). Surakarta: Universitas Sebelas Maret.

Burghouts, J., et al. (2017). Childhood Vaccine Acceptance and Refusal among Warao Amerindian Caregivers in Venezuela; A Qualitative Approach. PLoS One, 1-15.

Class, A. Y. E. C. (2014). Suku Samin Yang Luhur. Jurnal Indonesia Kaya. http://www. Indonesiakaya.com/jurnal/detail/suku-saminyang-luhur.

Darmastuti, R., \& Prasela, M. K. (2010). Two Ways Communication: Sebuah Model Pembelajaran dalam Komunitas Samin di Sukolilo Pati. Jurnal Ilmu Komunikasi, 8(2), 204-216.

Detik Health. (2015). 4 Golongan Anti Vaksin di Indonesia. Detikcom. https:// health.detik.com/anak-dan-remaja/d2896315/4-golongan-antivaksin-yang-ada -di-indonesia/5/\#news. Diakses tangal 26 Maret 2020.

Dinas Kesehatan Kabupaten Pati. (2017). Profil Kesehatan Kabupaten Pati. Pati: DKK Pati.

Kementerian Kesehatan Republik Indonesia. (2018). Profil Kesehatan Indonesia Tahun 2017. Jakarta: Kemenkes RI.

Kementerian Kesehatan Republik Indonesia. (2011). Pedoman Umum Pengelolaan Posyandu. Jakarta: Kemenkes RI.

Kementerian Kesehatan Republik Indonesia. (2017). Pmk no.12 tentang Penyelenggaraan Imunisasi Tahun 2017. Jakarta: Kemenkes RI. 
Lestari, P. (2009). Analisis Perubahan Sosial pada Masyarakat Samin (Studi Kasus di Desa Mendenrejo, Kecamatan Kradenan, Blora). Dimensia: Jurnal Kajian Sosiologi, 2 (2), 20-31.

Mardikantoro, H. B. (2017). Samin Kajian Sosiolinguisik. (K. Abd., Ed.) (Cetakan, 2). Yogyakarta: Forum.

Nafiah, U., \& Setiawati, I. (2019). Kajian Pelayanan Antenatal K4 dan Pertolongan Persalinan di Puskesmas Kabupaten Pati. Jurnal Litbang: Media Informasi Penelitian, Pengembangan dan IPTEK, 15(2), 121132.

Noya, A. B. I. (2018). Tunda dulu Imunisasi jika Anak Mengalami ini. https:// www.alodokter.com/bunda-tunda-duluimunisasi-jika-anak-mengalami-ini. Diakses tanggal 25 Maret 2020.

Permenkes RI Nomor 12 Tahun 2017 Tentang Penyelenggaraan Imunisasi.

Prabandari, G. M., Musthofa, S. B., \& Kusumawati, A. (2018). Beberapa Faktor yang Berhubungan dengan Penerimaan Ibu terhadap Imunisasi Meales Rubella pada Anak SD di Desa Gumpang, Kecamatan Kartasura, Kabupaten Sukoharjo. Jurnal Kesehatan Masyarakat, 6(4), 573-581.

Priyoto. (2018). Teori Sikap dan Perilaku dalam Kesehatan (2nd ed.). Yogyakarta: Nuha Medika.

Puri, Y. E. (2016). Pengaruh Persepsi Ibu tentang Imunisasi Ditinjau dengan Health Belief Model terhadap Kelengkapan Status Imunisasi (Thesis). Surakarta: Universitas Sebelas Maret

Puskesmas Sukolilo I Kabupaten Pati. (2017). Profil Kesehatan Puskesmas Sukolilo I. Pati: Puskesmas Sukolilo I.

Rahmawati, A. I., \& Wahyuni, C. U. (2014). Faktor yang Memengaruhi Kelengkapan Imunisasi Dasar di Kelurahan Krembangan Utara. Jurnal Berkala Epidemiologi, 2(1), 59-70.
Sa'ida, I. A. (2015). Kehidupan Masyarakat Suku Samin di Kabupaten Bojonegoro. Jurnal Geografi, 13(1), 51-59.

Sri, P., Indah, V., \& Lestari, P. (2017). Masyarakat Samin Ditinjau dari Sejarah dan NilaiNilai Pendidikan Karakter. Journal UNY, 13 (1).

Sugiyono. (2016). Metode Penelitian Kualitatif, Kuantitatif dan R\&D (23rd ed.). Bandung: CV Alfabetha.

Sugiyono. (2018). Metode Penelitian Kualitatif. Bandung: Alfabeta.

Sulistiyani, P. (2017). Gambaran Penolakan Masyarakat terhadap Imunisasi Dasar Lengkap bagi Balita. Jurnal Kesehatan Masyarakat, 5(5), 1081-1091.

Trianingsih, Z., Kibtiyah, M., \& Umriana, A. (2017). Dakwah Fardiyah melalui Pernikahan secara Islam pada Masyarakat Samin (Sedulur Sikep) di Dusun Bombong Desa Baturejo Kecamatan Sukolilo Kabupaten Pati. Jurnal Ilmu Dakwah, 37(1), 4582.

Undang-Undang Dasar Negara Republik Indonesia Tahun 1945 tentang Hak Asasi Manusia Pasal 28 H (2002).

Undang-Undang Republik Indonesia Nomor 36 Tahun 2009 tentang Kesehatan.

Utviaputri, L. P. (2018). Faktor Pengaruh Petunjuk untuk Bertidak terhadap Kelengkapan Imunisasi Dasar di Puskesmas Kenjeran Surabaya. Jurnal Promkes, 6(1), 47-58.

Wahyunarni, Y. I., Ahmad, R. A., \& Ratnawati, A. T. (2018). Community's Perception of Measles Immunization in Sleman. Berita Kedokteran Masyarakat, 32(8), 281.

Widyastuti, R. (2017). Knowledge Relationship and Attitudes of Mothers of Toddlers with Accidental Events after Immunization at the Oebobo Public Health Center in 2016. Jurnal Info Kesehatan, 15(2), 306-316. 


\section{BIODATA PENULIS}

Penulis pertama Edi Siswanto, lahir pada tanggal 15 April 1975 di Kabupaten Pati. Pendidikan terakhir adalah Sarjana Kesehatan Masyarakat Stikes Cendekia Utama Kudus dan sedang menempuh pendidikan Magister Promosi Kesehatan Universitas Diponegoro (UNDIP) Semarang. Penulis saat ini bekerja di Puskesmas Sukolilo I Kabupaten Pati sebagai Penyuluh Kesehatan Masyarakat Muda.

Penulis kedua Ani Margawati, lahir pada tanggal 25 Mei 1965. Pendidikan terakhir adalah Doctor of Philosophy Medical Anthropology the University of Hull. Saat ini bekerja sebagai Kepala Departemen Gizi Fakultas Kedokteran Universitas Diponegoro (UNDIP) Semarang.

Penulis ketiga Antono Suryoputro, lahir pada tanggal 06 Maret 1957. Pendidikan terakhir Doctor of Philosophy Mahidol University. Saat ini bekerja sebagai Dosen dan Peneliti Bagian Analisis Kebijakan Kesehatan Fakultas Kesehatan Masyarakat Universitas Diponegoro (UNDIP) Semarang. 
